\title{
ANALISIS BIAYA PRODUKSI PADA PABRIK SELANG AIR DI PT. MASPION IV SURABAYA
}

\author{
*(Rusdiyanto \\ Fakultas Ekonomi, Universitas Gresik \\ $\mathrm{Jl}$. Arif Rahman Hakim 2B Gresik \\ Telp. (031) 3981918, Faks. ( 031 ) 324706 \\ Email:jpias.unigres@gmail.com
}

\begin{abstract}
ABSTRAK
Analisis biaya produksi adalah suatu kegiatan yang menguraikan semua biaya yang berhubungan dengan fungsi poduksi yaitu semua biaya dalam rangka pengolahan vahan baku menjadi produk selesai yang siap untuk dijual. Tujuan penelitian ini adalah untuk mengetahui berapa biaya produksi yang mengalami in-efisiensi. Penelitian dilakukanterhadap PT Maspion IV Surabaya yang memproduksi selang air. Objek penelitianya adalah análisis biaya produksi pada pabrik selang PT Maspion IV Surabaya tahun 2013. Hasil pengujian menunjukkan bahwa biaya bahan baku mengalami in-efisiensi biaya karena dalam proses produksinya untuk pengaturan kecepatan mesin produksinya dipercepat,hal ini dikarenakan untuk mencapainya sebuah target yang diinginkan. Dalam biaya tenaga kerja mengalami efisiensi biaya, karena adanya karyawan yang tidak masuk kerja dan itu akan mengurangi jumlah jam dari standar yang ditetapkan. Sedangkan untuk staff pada PT Maspion IV mengalami pengurangan satu staff dikarenakan adanya pemutasian staff ke divisi lain.dan itu juga akan mengurangi jumlah biaya pada standar yang telah ditetapkan. Untuk biaya overhead pabrik juga mengalami in-efisiensi biaya dikarenakan semakin banyaknya bahan baku yang dikeluarkan serta semakin banyaknya jumlah produksi selang yang dihasilkan maka akan semakin banyak pula jumlah biaya overhead pabrik yang dikeluarkan.
\end{abstract}

Kata Kunci : Analisis Biaya Produksi

\section{PENDAHULUAN}

Pada umumnya suatu perusahaan memiliki target atau tujuan untuk dicapai, salah satu tujuan tersebut adalah untuk mendapatkan hasil yang diinginkan dengan meminimalkan pengeluaran biaya-biaya yang terjadi dalam proses produksi. Berhasil atau tidaknya sering dimanfaatkan sebagai ukuran untuk menilai kinerja suatu perusahaan. Unsur - unsur yang menjadi bagian pembentuk keberhasilan adalah biaya.

Biaya merupakan salah satu sumber informasi yang paling penting dalam analisis strategik perusahaan. Proses penentuan dan analisis biaya pada perusahaan dapat menggambarkan suatu kinerja perusahaan pada masa yang akan datang. Pada dasarnya masalah yang sering timbul dalam suatu perusahaan adalah perencanaan biaya oleh suatu perusahaan tidak sesuai 
dengan apa yang terjadi sesungguhnya (realisasi biaya). Oleh sebab itu untuk dapat mencapai produksi yang efisien, maka diperlukan suatu pengendalian terhadap biaya produksi yang akan dikeluarkan. Pengendalian biaya produksi merupakan penggunaan utama dari akuntansi dan analisis biaya produksi. Komponen biaya utama yaitu upah, bahan baku dan overhead pabrik perlu dipisahkan menurut jenis biaya dan juga menurut pertanggungjawaban. Pengendalian terhadap biaya dapat diukur dengan tingkat efisiensi biaya yang dianggarkan dengan biaya sesungguhnya.

Efisiensi biaya dapat diukur dengan cara membandingkan antara biaya sesungguhnya dengan biaya yang dianggarkan selanjutnya disebut biaya standar (Carter Usry, 2006 : 12). Dalam hal ini biaya standar yang telah ditetapkan perusahaan akan dibandingkan dengan biaya realisasi (biaya sesungguhnya yang terjadi) selama proses produksi.

\section{LANDASAN TEORI}

\section{Analisis Biaya Produksi}

a. Pengertian Analisis Biaya Produksi Menurut Mulyadi dalam buku "Akuntansi Manajemen" (2001:51) mengemukakan bahwa :

"Analisis biaya produksi adalah suatu kegiatan yang menguraikan semua biaya yang berhubungan dengan fungsi produksi yaitu semua biaya dalam rangka pengolahan vahan baku menjadi produk selesai yang siap untuk dijual".

b. Analisis Varians

Analisis Varians adalah suatu proses sistematis untuk mengidentifikasi, melapor dan

\begin{tabular}{|c|}
\hline $\begin{array}{l}\text { menjelaskan varians } \\
\text { penyimpangan hasil } \\
\text { sesungguhnya dari hasil } \\
\text { diharapkan atau dianggarkan } \\
\text { dimaksud dengan analisis } \\
\text { dalam penelitian ini adalah } \\
\text { untuk mengidentifikasi } \\
\text { penyimpangan antara } \\
\text { produksi yang dianggarkan } \\
\text { realisasi biaya produksi } \\
\text { terjadi. }\end{array}$ \\
\hline
\end{tabular}

\section{METODE PENELITIAN}

Penelitian ini merupakan jenis penelitian deskriptif yaitu penelitian yang dilakukan untuk mengetahui dan menjelaskan karakteristik variabel yang akan diteliti dalam suatu situasi.Lokasi penelitian dan pengambilan data dilakukan di PT Maspion IV yang berlokasi di desa Roomokalisari, kecamatan benowo, Surabaya Jawa Timur. Jenis data yang digunakan dalam penelitian skripsi ini adalah data kualitatif dan data kuantitatif.

\section{HASIL PENELITIAN DAN PEMBAHASAN}

\section{Hasil Penelitian}

a. Pembahasan Rumusan Masalah

Selama ini PT Maspion IV sebenarnya sudah melakukan kegiatan analisis biaya produksi. Hal ini seperti dilihat pada laporan yang dihasilkan oleh bagian akuntansi perusahaan yang didalamnya sudah terdapat data - data yang berhubungan biaya produksi. Namun perusahaan masih belum menyajikan laporan biaya produksi secara khusus yang berisikan jumlah biaya yang dikeluarkan untuk peningkatan produksinya, Semua informasi tentang biaya, masih dicatat dalam laporan biaya produksi. Berikut 
ini disajikan laporan biaya produksi PT Maspion IV selama tahun 2013 :

b. Biaya Produksi

b.1 Biaya Bahan Baku

\section{b.1.1Bahan Baku Langsung}

Dalam pembuatan selang air yang paling utama adalah bahan baku sebagai berikut :

\section{a). Resin FJ $65 \mathrm{~S}$}

Dalam pembuatan selang air ini untuk menghasilkansatu proses campuran (mixing) bahan selang dibutuhkan resin fj $65 \mathrm{~s}$ sebanyak $100 \mathrm{~kg}$ (4 sak), dan dari $100 \mathrm{~kg}$ tersebut akan menghasilkan campuran sebanyak 16 sak. Masing masing satu sak beratnya $25 \mathrm{~kg}$. setelah mendapat hasil campuran akan diproses ke dalam mesin selang,dan dari proses pembuatan selang tersebut $25 \mathrm{~kg}$ (1 sak) campuran akan menghasilkan 5 roll selang.

b). DOP

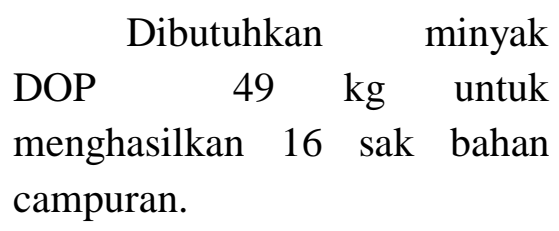

b.1.2 Biaya Bahan Penolong

Bahan penolong dalam pembuatan selang air adalah :

a). Air

1) Diperlukan $54 \mathrm{~m}^{3}$ air dengan harga per meter kubiknya $\left(\mathrm{m}^{3}\right)$ bagian pembelian, sedangkan pencatatan dilakukan oleh bagian pembelian dan akuntansi

2) Prosedur Perhitungan Fisik Persediaan

b). Tali

Biaya yang dikeluarkan untuk pemakaian talisebagai pengikat selang air.

\section{c. Biaya Tenaga Kerja}

Dalam produksi selang ini, PT Maspion IV mempekerjakan 72 pekerja yang terdiri dari :

1). 65 (enam puluh lima ) karyawan harian, dengan rincian biaya gaji sebesar Rp. 10,060/ Per jam.

2). 7 ( tujuh ) staff bulanan, dengan biaya gaji yang berbeda - beda menurut masing - masing bagian. Untuk total biaya gaji 7 ( orang ) staff tahun 2013 adalah sebesar Rp. 472,240,044/tahun.

d. Biaya Overhead Pabrik

Biaya yang dikeluarkan untuk memproduksi selang air selain biaya bahan baku dan biaya tenaga kerja adalah :
1). Biaya Listrik
Biaya listrik yang dikeluarkan PT Maspion IV divisi selang air per bulan rata - rata sebesar Rp. 47,124,820.
2). Biaya PDAM
Biaya PDAM yang dikeluarkan PT Maspion IV divisi selang air per bulan rata - rata $\mathrm{Rp}$. 649,185.83.

\section{Analisis Biaya Produksi}

PT Maspion IV mengolah produknya melalui satu departemen produksi. Ada punjumlah biaya yang dikeluarkan selama Tahun 2013 adalah sebagai berikut:

a. Data Produksi

Biaya Bahan Baku

Rp.16,520,545,240

BiayaTenagaKerj

Rp. 2,203,475,504

Biaya Overhead Pabrik

Rp. $687,504,060$

Total Biaya Produksi

Rp.19,411,524,804 
Jumlah produk yang dihasilkan selama tahun 2013 adalah :

Produk Jadi 33,542 Roll

b. Laporan Biaya Produksi

Data produksi :

Produk yang dikirim kegudang 30,415 Roll

Produk dalam proses akhir

3,127 Roll Jumlah produk yang dihasilkan 33,542 Roll

Biaya yang dibebankan dalam tahun 2013 :

\section{Analisis Varians}

Berikut ini adalah rincian analisis varians biaya selama tahun 2013 yang meliputi biaya bahan baku, biaya tenaga kerja, dan biaya overhead pabrik sebagai berikut :

a. AnalisisBiayaBahan Baku

1). Selisih Harga Kuantitas Realisasi x ( Harga Real - Harga standar )

a). Resin FJ $65 \mathrm{~S}$ 1,006,260 kg x ( Rp. 9,298.56Rp.8,976 ) =

Rp.324,579,226

(Un-favorable )

b). DOP

493,067 kg x ( Rp. 14,529 Rp.12,877 ) = Rp. 814,546,684

(Un-favorable)

2). Selisih Kuantitas / Efisiensi

( Kuantitas real - kuantitas standar ) $\mathrm{x}$ Harga standar

a) Resin FJ $65 \mathrm{~S}$

$(1,006,260 \mathrm{~kg}-1,147,705 \mathrm{~kg}) \mathrm{x}$

Rp.8,976 = Rp.1,269,610,320 (favorable)

b) DOP

( 493,067 kg - 562,375 kg ) x Rp. $12,877=-R p .892,479,116$ (favorable)

b. Analisis Biaya Tenaga Kerja

1) Karyawan a). Selisih tariff upah langsung

Kuantitas realisasi x ( Upah real

- Upah standar )

172,091 jam x ( Rp.10,060 -

Rp. 12,575 ) = -Rp.432,808,865 (favorable)

b). Selisih efisiensi upah langsung / jam kerja

(Kuantitas real - Kuantitas standar) $\mathrm{x}$ Upah standar ( 172,091 jam - 211,644 jam ) $\mathrm{x}$ Rp.12,575=-Rp.497,378,975 (favorable)

2). Staff

Kuantitas realisasi x ( Upah real - Upah standar )

12 bln x ( Rp.39,353,337 -

Rp.56,426,708 ) =

- Rp.204,880,452

(favorable)

c. Analisis biaya overhead pabrik

1). Selisih terkendaikan

Kuantitas realisasi x (Harga real Harga standar)

a) Biaya listrik

12 bln x (Rp.47,124,820 -

Rp.38,090,288)

Rp.108,414,384 (favorable)

b) Biaya PDAM $12 \ln \mathrm{x}$ (Rp. 649,185.83 - Rp. 566,870) = Rp.987,790 (favorable)

Berdasarkan analisis varians tersebut, jika dilihat dari perhitungan analisis varians diatas. Maka, analisis biaya bahan baku untuk selisih harga mengalami in-efisiensi biaya. Dan untuk analisis biaya bahan baku selisih kuantitas mengalami efisiensi biaya, Sedangkan untuk analisis biaya tenaga kerja pada karyawan mengalami inefisiensi biaya dan untuk analisis biaya tenaga kerja staff mengalami efisiensi biaya. Serta analisis overhead pabrik mengalami efisiensi biaya. 


\section{KESIMPULAN DAN SARAN Kesimpulan}

Analisis biaya produksi yang dilakukan di pabrik selang Surabaya pada tahun 2013, menunjukkan total biaya produksinya sebesar Rp.19,411,524,804 ( sembilan belas miliar empat ratus sebelas juta limaratus dua puluh empat ribu delapan ratus empat rupiah ) untuk hasil produksi 33,542 roll.

Sedangkan untuk analisis variansnya adalah biaya bahan baku untuk selisih harga mengalami inefisiensi biaya dikarenakan harga realisasi lebih besar dari pada harga standar yang ditentukan oleh perusahaan. Hal ini dikarenakan kenaikan pada kurs dollar pada tahun 2013. Dan untuk analisa biaya bahan baku pada selisih kuantitas mengalami efisiensi biaya dikarenakan kuantitas realisasinya lebih kecil dari kuantitas standar yang ada. Hal ini dikarenakan jumlah pesanan lebih sedikit dari pada sebelumnya dan itu menyebabkan penggunaan bahan baku yang tidak sesuai dengan standar yang telah ditetapkan.

Sedangkan untuk analisis biaya tenaga kerja tahun 2013 mengalami efisiensi biaya dikarenakan tarif upah realisasi dan kuantitas realisasi lebih kecil dari pada upah standar dan kuantitas standarnya. Hal ini dikarenakan adanya pemutasian staff ke divisi lain dan itu akan menyebabkan terjadinya pengurangan gaji staff dan jam kerja staff.

Untuk analisis biaya overhead pabrik tahun 2013, mengalami efisiensi biaya dikarenakan biaya realisasi listrik dan PDAM lebih besar dari pada biaya standar listrik dan PDAM yang telah ditentukan oleh perusahaan.

Dengan adanya analisis varians dapat diketahui biaya apa saja yang mengalami in-efisiensi biaya dan efisiensi biaya.

\section{Saran}

Berdasarkan uraian kesimpulan diatas maka saran yang diberikan untuk perusahaan terkait yaitu :

1. PT Maspion IV dapat menerapkan analisis biaya produksi sebagai alat bantu dalam pengendalian biaya perusahaan dimana dapat diketahui nilai penjualan perusahaan sehingga perusahaan tidak mengalami kerugian dan analisis ini dapat memberikan informasi mengenai biaya yang harus dicapai.

2. PT Maspion IV juga dapat menggunakan analisis varians untuk mengetahui perbandingan antara anggaran dengan realisasi biaya produksi.

\section{DAFTAR PUSTAKA}

Anwar, Saifuddin. 2010 .Metode Penelitian . Edisi Pertama, Cetakan X. Jogjakarta:Pustaka Belajar.

Baridwan, Zaki. 2004. Intermediate Accounting. Edisis Kedelapan. Yogyakarta:BPFE.

Carter dan Usry. 2006. Akuntansi Biaya. Buku 1\&2, Edisi 13. Jakarta:Salemba Empat.

Garrison, and Noreen, 2000. Akuntansi Manajerial. Jilid Satu. Terjemahan oleh Totok Budi Santoso, Salemba Empat, Jakarta. 
Garrison, Noreen \& Brewer. 2007. Akuntansi Manajerial. Diterjemahkan oleh Nuri pengendalian Laba, Jakarta : Hinduan. Buku 2. Edisi 11. Jakarta: Salemba Empat.

Hansen, D. R. dan Maryanne M. Mowen, 2006, Akuntansi Manajemen, Edisi 7, Jakarta: Salemba.

Hidayat, Lukman. 2013. Analisis Biaya

Produksi dalam Meningkatkan

Profitabilitas Perusahaan.

Skripsi. Fakultas Ekonomi.

Kusnadi et al, 2002, Akuntansi Manajemen, Yogyakarta:BPFE Yogyakarta.

Mulyadi, Akuntansi Biaya, Edisi 6, 2005,Yogyakarta : STIE YKPN.

Mulyadi, 2001, Akuntansi Manajemen, Edisi 4, Yogyakarta.

Nafarin.M, 2009, Penganggaran Perusahaan, Edisi 3, Penerbit Salemba Empat.

Nafarin.M, 2004, Penganggaran Perusahaan, Jakarta : Salemba Empat.

Rasyid, Muhammad. 2013. Analisis Biaya Produksi pada Perusahaan Susu Sapi Anugerah di Kecamatan Kotamadya Kediri. Skripsi, Fakultas Ekonomi.

Therina O.K, Eka. 2008. Analisis Biaya Produksi pada Usaha Tahu di Pabrik Tahu Bangkalan. Skripsi, Fakultas Ekonomi.

Salvatore, Dominick, 2005. Managerial Economics: Ekonomi Manajerial dalam Perekonomian Global. Jakarta:Salemba Empat. Welsch, G.A., Hilton, Ronald W., and Gordon. Paul N, 2004, Anggaran : Perencanaan dan 